\title{
Serological Abnormalities in Patients with Liver Disease
}

\author{
I. A. D. BOUCHIER, $*$ † M.D., M.R.C.P. ; K. RHODES, $*$ M.D. \\ SHEILA SHERLOCK,* M.D., F.R.C.P., F.R.C.P.ED.
}

Brit.med. F., 1964, 1, 592-594

Patients with active cirrhosis of the liver may show evidence of multiple system involvement (Read, Sherlock, and Harrison, 1963). The suggestion has also been made that in such patients autoimmune phenomena play an important part in the pathogenesis of the disease (Mackay, Taft, and Cowling, 1956). These findings prompted us to undertake an investigation into the frequency with which antinuclear factors (A.N.F.) and other autoantibodies occur in the sera of patients with various types of liver disease.

\section{Patients Studied and Diagnostic Groups}

A total of 116 cases of liver disease were studied, of which 104 were shown to have some form of cirrhosis.

Alcoholic Cirrhosis.-This group comprised 10 patientsseven males and three females. Their ages varied from 30 to 69 , with a mean of 50.5 years. All gave a history of excessive alcohol intake and many showed peripheral neuropathy, parotid enlargement, and gynaecomastia. Liver biopsies revealed portal cirrhosis with a variable degree of fatty infiltration: Mallory's hyaline was present in some.

"Fuvenile" Cirrhosis.-There were 38 patients-18 males and 20 females-in this group. Their ages varied from 6 to 67 , with a mean of 27 years. The term " juvenile" cirrhosis describes a group of patients showing all or most of the following features: marked hypergammaglobulinaemia, elevated serum transaminase and serum bilirubin levels, and cirrhosis, usually post-necrotic in character (Read et al., 1963). A prominent feature of the liver histology is the plasma-cell and lymphocytic infiltration and the tendency for the liver cells to take up a rosette-like formation. This group resembles those cases described by Bearn, Kunkel, and Slater (1956), and called plasma-cell hepatitis, active chronic hepatitis, and lupoid hepatitis (Mackay and Wood, 1962).

Primary Biliary Cirrhosis.-There were 12 patients in this group, all females. Their ages ranged from 33 to 59 , with a mean of 48 years. Pruritus, intrahepatic cholestasis, and an elevated serum cholesterol were prominent features of the illness (Sherlock, 1959). The majority had undergone a previous laparotomy, when the patency of the biliary tree had been established. Liver histology was characterized by aggressive, infiltrating fibrosis in the portal zones, inconspicuous bileductules, and foci of lymphocytes.

Virus Hepatitis.-There were 12 patients in this group-five males and seven females. Their ages varied from 26 to 61 , with a mean of 36 years. All had been admitted in the second or third week of their illness, the majority because of severe cholestasis. This group therefore does not represent the usual type of virus hepatitis.

\section{Investigations}

Liver histology, obtained by percutaneous liver biopsy or at operation, was available on all the patients studied except the \footnotetext{
^ Departments of Medicine and of Physical Medicine and Rheumatology,
Royal Free Hospital, London.

† Present address: Massachusetts Memorial Hospital, Boston.
}

occasional patient in whom the platelet count or prothrombin time made the procedure unsafe. Tests of liver function undertaken included prothrombin time, full blood count, serum alkaline phosphatase, and serum aspartate transaminase levels. Paper electrophoresis was carried out on a vertical tank using barbitone buffer, $p \mathrm{H}$ 8.6, 0.1 molar, and after staining with naphthalene black the strips were scanned on a " chromoscan."

L.E. Cell Test.-All sera were tested on three or more occasions by the indirect method (Dacie, 1956).

Antinuclear Factor (A.N.F.).-The immuno-fluorescent method (Holborow, Weir, and Johnson, 1957) was employed. Fresh snap-frozen rat liver was used as nuclear substrate. Antihuman globulin was produced in rabbits by repeated injections of human gamma-globulin, and this was conjugated with fluorescein isothiocyanate (Marshall, Eveland, and Smith, 1958). Sera were tested at dilutions of $1: 5$ to $1: 1000 ; 1: 5$ was regarded as the lowest positive titre.

Two tests for "rheumatoid" factors were employed: (1) Sheep-Cell Agglutination Test (S.C.A.T.). A modified RoseWaaler technique was used. Fresh sheep cells were obtained from Burroughs Wellcome. A titre of 1:32 and over was regarded as positive. (2) "Slide Latex" Test: Latex particles coated with aggregated human gamma-globulin were obtained from Baxter Laboratories and Stayne Laboratories Ltd., and tested against $1: 20$ dilutions of serum. Weakly positive reactions were discounted.

Thyroglobulin Antibodies.-The tanned-red-cell agglutination technique was employed, using formolized thyroglobulincoated sheep cells supplied by Burroughs Wellcome (Fulthorpe, Roitt, Doniach, and Couchman, 1961). For the purpose of this study titres of $1: 250$ and over were regarded as positive.

\section{Results}

Electrophoretic scan of the serum showed increased gammaglobulin peaks in the majority of patients studied and exceptionally high levels were seen in seven patients with juvenile cirrhosis. Although patients with liver disease had an increased incidence of positive sheep-cell agglutination and latex tests compared with the normal population, the percentage of positive reactions for " rheumatoid" factors was much higher in juvenile, cryptogenic, and primary biliary cirrhosis (Table I).

TABLE I.-Incidence of Positive Reactions for Rheumatoid Arthritis in Liver Disease

\begin{tabular}{|c|c|c|c|c|c|c|}
\hline & & \multirow{2}{*}{$\begin{array}{l}\text { No. of } \\
\text { Patients }\end{array}$} & \multicolumn{2}{|c|}{ S.C.A.T. } & \multicolumn{2}{|c|}{ Latex } \\
\hline & & & No. & $\%$ & No. & $\%$ \\
\hline $\begin{array}{l}\text { Alcoholic cirrhosis } \\
\text { Juvenile cirrhosis } \\
\text { Cryptogenic cirrhosis } \ldots \\
\text { Primary biliary cirrhosis } \\
\text { Virus hepatitis .. }\end{array}$ & $\begin{array}{l}\ldots \\
\because \\
\cdots\end{array}$ & $\begin{array}{l}10 \\
38 \\
44 \\
12 \\
12\end{array}$ & $\begin{array}{r}1 \\
8 \\
10 \\
4 \\
1\end{array}$ & $\begin{array}{r}10 \\
21 \\
23 \\
33 \\
8\end{array}$ & $\begin{array}{r}3 \\
20 \\
17 \\
5 \\
2\end{array}$ & $\begin{array}{l}30 \\
53 \\
39 \\
42 \\
17\end{array}$ \\
\hline
\end{tabular}

Patients with alcoholic cirrhosis and particularly those with virus hepatitis had a lower incidence of positive tests. However, the differences were not sufficiently marked to be of diagnostic value. In all patients the latex test was positive with 
greater frequency than the sheep-cell test. This was to be expected as the slide latex test is highly sensitive and will detect very small amounts of abnormal macroglobulin in serum. It is more sensitive than other latex methods (Lane and Decker, 1960) ; therefore, to avoid including false-positive reactions, all weakly positive latex tests were disregarded. Positive latex tests varied in the different diagnostic groups of liver disease from $17 \%$ in 12 patients with virus hepatitis to $39 \%$ in 44 cases with cryptogenic cirrhosis and $42 \%$ in 12 cases with primary biliary cirrhosis.

The sheep-cell agglutination test is a less sensitive test than the latex, but it is more specific for $19 \mathrm{~S}$ gamma-globulins of the rheumatoid factor type. Although the overall incidence of positive reactions was found to be lower than that of the latex test it is of interest that positive sheep-cell agglutination reactions in juvenile, cryptogenic, and primary biliary cirrhosis $(21 \%, 23 \%$, and $33 \%$ respectively) had a much greater incidence than in alcoholic cirrhosis $(10 \%)$ and virus hepatitis (8\%) (Table I).

A strikingly high incidence of antinuclear antibodies was found in $20(42 \%)$ out of 38 patients with juvenile cirrhosis. Five $(10 \%)$ out of 44 patients with cryptogenic cirrhosis and one out of 12 with primary biliary cirrhosis had antibodies against nuclear constituents. The majority of positive A.N.F. tests were to a low titre (Table II). Antinuclear antibodies

TABLE II.-Incidence of Positive A.N.F. Titres in Various Types of Liver Disease

\begin{tabular}{|c|c|c|c|c|c|c|c|}
\hline & \multicolumn{2}{|c|}{ No. of Patients } & \multicolumn{5}{|c|}{ Titres } \\
\hline & Tested & Positive & $1: 5$ & $1: 10$ & $1: 20$ & $1: 100$ & $1: 200$ \\
\hline $\begin{array}{l}\text { Juvenile cirrhosis } \\
\text { Cryptogenic cirrhosis } \ldots \\
\text { Primary biliary cirrhosis } \\
\text { Alcoholic cirrhosis } \quad \ldots \\
\text { Virus hepatitis .. }\end{array}$ & $\begin{array}{l}38 \\
44 \\
12 \\
10 \\
12\end{array}$ & $\begin{array}{l}16(42 \%) \\
5(10 \%) \\
1(8 \%) \\
0 \\
0\end{array}$ & $\begin{array}{l}8 \\
3 \\
- \\
- \\
-\end{array}$ & $\begin{array}{l}5 \\
1 \\
1 \\
- \\
-\end{array}$ & $\begin{array}{l}2 \\
- \\
-\end{array}$ & $\begin{array}{l}\overline{1} \\
\bar{z}\end{array}$ & $\begin{array}{l}1 \\
- \\
- \\
-\end{array}$ \\
\hline
\end{tabular}

were not detected in alcoholic cirrhosis and viral hepatitis. Patients with antinuclear antibodies did not differ clinically from other patients in their group. No correlation was found between the severity of the disease and a positive A.N.F. Costicosteroid treatment did not lead to a fall in antinuclear antibody titre.

Only six out of 38 patients with juvenile cirrhosis had positive L.E. cell tests. All the other patients with liver disease had negative L.E. cell preparations. Thyroglobulin antibodies were detected in from 7 to $11 \%$ of patients suffering from alcoholic, juvenile, and cryptogenic cirrhosis and virus hepatitis. Two of 12 patients with primary biliary cirrhosis gave a positive value. The positive thyroglobulin titres were usually low $(1: 250)$; two patients, however, had titres of $1: 25,000$ and only one patient, a case of cryptogenic cirrhosis, had a titre of $1: 2,500,000$ (Table III) and was also suffering from Hashi-

TABLE III.-Incidence of Positive Thyroglobulin Antibody Titres in Various Types of Liver Disease

\begin{tabular}{|c|c|c|c|c|c|c|c|}
\hline & \multicolumn{2}{|c|}{ No. of Patients } & \multicolumn{5}{|c|}{ Titres } \\
\hline & Tested & Positive & $\begin{array}{c}1: \\
250\end{array}$ & $\begin{array}{c}1: \\
2,500\end{array}$ & $\begin{array}{c}1: \\
25,000\end{array}$ & $\begin{array}{c}1: \\
250,000\end{array}$ & $\begin{array}{c}1: \\
2,500,000\end{array}$ \\
\hline $\begin{array}{l}\text { Alcoholic cirrhosis. . } \\
\text { Juvenile cirrhosis . } \\
\text { Cryptogenic cirrhosis } \\
\text { Primary biliary cirr- }\end{array}$ & $\begin{array}{l}10 \\
38 \\
44\end{array}$ & $\begin{array}{l}1(10 \%) \\
4(11 \%) \\
3(7 \%)\end{array}$ & $\begin{array}{l}1 \\
4 \\
2\end{array}$ & $\bar{z}$ & $\begin{array}{l}\bar{z} \\
\overline{-}\end{array}$ & $\overline{-}$ & $\overline{-}$ \\
\hline $\begin{array}{ll}\text { hosis } & \quad \\
\text { Virus hepatitis } & \cdots\end{array}$ & $\begin{array}{l}12 \\
12\end{array}$ & $\begin{array}{l}2(17 \%) \\
1(8 \%)\end{array}$ & 1 & $\overline{-}$ & $\begin{array}{l}1 \\
1\end{array}$ & - & - \\
\hline
\end{tabular}

moto's disease. Hill (1961) established that the incidence of thyroglobulin antibodies with titres of $1: 25$ and $1: 250$ was $10 \%$ for middle-aged women free from the apparent thyroid disease, and our series of patients with liver disease does not differ appreciably from this.

Associated Diseases.-Many of the patients with juvenile cirrhosis showed associated lesions in other organs. Nine of these had long-standing ulcerative colitis; renal biopsies in 7 of the 12 patients revealed early changes suggestive of a lupus glomerulitis (Silva, 1963); one had arthritis and two had myxoedema. Five patients with cryptogenic cirrhosis were diabetic, four developed primary cancer of the liver, three had disease of the thyroid gland, and one had ulcerative colitis. One patient with biliary cirrhosis was diabetic and another had ulcerative colitis. None of the other varieties of liver disease manifested any associated disease. The incidence of positive serological tests did not vary in those patients with and those without multiple system involvement.

\section{Repeated Serology}

Repeated investigations in 26 patients over a period of one year showed only minor changes in sheep-cell titre although the occasional development of positivity in previously negative cases, and vice versa, was encountered in both the sheep-cell and latex tests. A.N.F. results were remarkably consistent. No correlation was found between serological and clinical changes.

\section{Discussion}

Patients with certain types of liver disease are known to have a high incidence of circulating antibodies as revealed by the sheep-cell agglutination, latex, and A.N.F. tests (Weir, Holborow, and Johnson, 1961 ; Holborow, Asherson, and Johnson, 1963). Our work confirms these findings, positive results being particularly frequent in patients with juvenile cirrhosis and cryptogenic cirrhosis. Dresner and Trombly (1959), using inhibition techniques, found a high incidence of positive reactions for rheumatoid factors in liver disease.

The frequency of positive tests for thyroglobulin antibodies in liver disease, as with all immunological procedures, depends on the technique used. Skanse and Nilsson (1961, 1962), using the same techniques as ourselves, also found the incidence for thyroglobulin antibodies to be similar to that found in the normal subject.

The incidence of positive S.C.A.T. in the normal population is $5.4 \%$ (Ball and Lawrence, 1961). There is therefore a definite increase in patients with liver disease. The S.C.A.T. and the latex test depend upon the presence in serum of $19 \mathrm{~S}$ macroglobulins which migrate electrophoretically with the gammaglobulins (Franklin et al., 1957). Most of the work on these factors has been done with the sera of sufferers from rheumatoid arthritis. Franklin et al. (1951), however, found electrophoretically similar abnormal proteins in the serum of patients with cirrhosis. It is therefore not surprising that cirrhotic patients also show positive results for the rheumatoid tests. Bonomo, Lo Spalluto, and Zift (1963) showed by chromatographic studies of serologically active sera from cirrhotic patients that the rheumatoid-factor-like substance was a $19 \mathrm{~S}$ macroglobulin. Positive results for these tests are also found in other diseases with hypergammaglobulinaemia such as chronic infections like tuberculosis (Singer et al., 1961) or connective-tissue disorders such as polyarteritis or sarcoidosis. The function of such abnormal proteins is not clear, and to date they have not been shown to exert any injurious effect on the parenchymal cells of the liver.

With a similar fluorescent technique the incidence of positive antinuclear antibodies in 132 normal subjects is less than $2 \%$ (Hijmans et al., 1961). Again the patients with liver disease show an increase in positivity particularly in the juvenile and cryptogenic groups. The majority of positive A.N.F. titres did not exceed $1: 10$. This is similar to results in rheumatoid arthritis, in which higher titres are found only infrequently while disseminated lupus erythematosus (D.L.E.) sera tend to be positive at titres exceeding $1: 200$. There is evidence that antinuclear activity may be contained in different fractions of 
gamma-globulin and that, in liver disease, the antibody is frequently a macroglobulin, while in D.L.E. it is predominantly a 7S gamma-globulin (Weir and Holborow, 1962). Positive A.N.F. tests were found in the absence of a positive L.E. cell test confirming the findings of Calabresi and Greenberg (1960), Weir et al. (1961), and Gökcen (1962). Such results indicate abnormal immunological activity (Mackay and Gajdusek, 1958 ; Mackay and Wood, 1962). Unlike Calabresi and Greenberg's (1960) findings, antinuclear antibodies were not found in the sera from alcoholic subjects.

The abnormal proteins responsible for these serological findings might be a response to the liver damage or they may be an expression of the underlying, possibly genetic, abnormality of the reticulo-endothelial system. Relatives of patients with rheumatoid arthritis show significant increases in the positivity rate of the S.C.A.T. compared with relatives of healthy subjects (Ball and Lawrence, 1961), and healthy first-degree relatives of patients with agammaglobulinaemia also have an increased incidence of positive rheumatoid agglutination tests as well as frequent abnormalities of gamma-globulin (Fudenberg, German, and Kunkel, 1962). Their presence in certain types of liver disease points to an abnormality of the immunological apparatus. Serological studies on relatives of patients with chronic liver disease might be useful in revealing a genetically determined abnormality.

\section{Summary}

Serological studies for the presence of antinuclear antibodies, "rheumatoid" factors, and thyroglobulin antibodies were undertaken in 116 patients suffering from alcoholic, " juvenile," cryptogenic, or primary biliary cirrhosis or from virus hepatitis.

An increased incidence of positive latex and sheep-cell agglutination tests, compared with normals, was found in all the varieties of liver disease studied. The highest number of positive results were encountered in juvenile, cryptogenic, and primary biliary cirrhosis ; in alcoholic cirrhosis and virus hepatitis the positivity rate was lower. The latex test was more often positive than the sheep-cell test.

Antinuclear antibodies were present in $42 \%$ of 38 sufferers from juvenile cirrhosis, and compared with normals their inci- dence was increased also in cryptogenic cirrhosis. They were not detected in patients with alcoholic cirrhosis and virus hepatitis.

The incidence of thyroglobulin antibodies did not differ from that found in normal subjects.

Our thanks are due to Professor D. N. Baron and Dr. W. J. D. Fleming for help with the investigation of the patients. The Irwin Strasburger Memorial Medical Foundation gave financial assistance.

\section{REPERENCES}

Ball, J., and Lawrence, J. S. (1961). Ann. rheum Dis., 20, 235.

Bearn, A. G., Kunkel, H. G., and Slater, R. J. (1956). Amer. F. Med., 21, 3. L., Lo Spalluto, J., and Ziff, M. (1963). Arth. and Rheum., 6, Bonomo,

Calabresi, P., and Greenberg, M. (1960). f. clin. Invest., 39, 976

Dacie, J.' V.'(1956). Practical Haematology, 2nd ed. Churchill, London. Dresner, E., and Trombly, P. (1959). New Engl. ₹. Med., 261, 981.

Franklin, E. C. Holman, H. R., Müller-Eberhard, H. J., and Kunkel, H. G. (1957). ₹. exp. Med., 105, 425.

Franklin, M., Bean, W. B., Paul, W. D., Routh, J. I., de la Huerga, J., and Popper, H. (1951). f. clin. Invest., 30, 729.

Fudenberg, H., German, J. L., and Kunkel, H. G. (1962). Arth. and Rheum., 5, 565 .

Fulthorpe, A. J., Roitt, I. M., Doniach, D., and Couchman, K. (1961). f. clin. Path., 14, 654 .

Gökcen, M. (1962). Ұ. Lab. clin. Med., 59, 533

Hijmans, W., Doniach, D., Roitt, I. M., and Holborow, E. J. (1961), Brit. med. F., 2, 909.

Hill, O. W. (1961). Ibid., 1, 1793.

Holborow, E. J., Weir, D. M., and Johnson, G. D. (1957). Ibid., 2, 732.

Holborow, E. J., Weir, D. M., and Johnson, G. D. (1957). Ibid., 2, 732. Carmichael, D. S. (1963). Ibid., 1, 656.
C. I

Lane, J. J., and Decker, J. L. (1960). F. Amer. med. Ass., 173, 982.

Mackay, I. R., and Gajdusek, D. C. (1958). Arch. intern. Med., 101, 30 Mackay, I. R., I., and Cowling, D. C. (1956). Lancet, 2, 1323.

- and Wood, I. J. (1962). Quart. F. Med., 31, 485.

Marshall J Eveland, W. C., and Smith, C. W. (1958). Proc. Soc. exp. Biol. (N.Y.), 98, 898.

Read, A. E., Sherlock, S., and Harrison, C. V. (1963). Gut, 4, 378.

Read, A. E., Sherlock, S., and Harrison, C.

Silva, H. (1963). Communication at the Renal Association, April, 1963. London.

Singer, J. M., Peralta, F. M., Lyons, H. D., and Plotz, C. M. (1961). Arthr. and Rheum., $4,124$.

Skanse, B., and Nilsson, S. B. (1961). Acta med. scand., 170, 599.

Weir, D. M., Holborow, E. J., and Johnson, G. D. (1961). Brit. med. f., 1, 933 . Holborow, E. J. (1962). Ann. rheum. Dis., 21, 40.

\title{
Heroin Addicts in a Casualty Department
}

\author{
A. J. CAMERON,* M.B., M.R.C.P.
}

During 1962 at least 30 heroin (diacetylmorphine) addicts were seen, 20 by the author personally, in a casualty department in central London. Nearly all these addicts volunteered the information that they took the drug, and injection marks were usually obvious. Hence it is thought that few addicts were missed among the patients attending the department. The number of known pethidine or morphine addicts seen here was much smaller.

Of the 30 addicts, 23 were men and seven women. Fifteen were known to be British, 12 were immigrants from Canada, and one came from the U.S.A. They were aged 19 to 46, with an average age of 29 years. The duration of addiction (as stated by the patient) was recorded in 20 cases. It ranged from six months to 18 years. Twelve British subjects had been addicted for an average of 6.7 years, whereas the

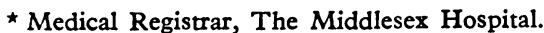

average duration of addiction in eight from across the Atlantic was 10.2 years.

\section{Drugs Taken}

All these patients were addicted to heroin, and most of them also took cocaine. The dose taken by any one addict varied from time to time. Possibly some exaggerated the amount they were taking in an attempt to get as large a supply as possible from the casualty officer. This was not usual, however, and where possible confirmation of the patient's story was obtained from his own doctor or a local chemist by telephone. The total amount of heroin taken in 24 hours (in four or more divided doses) was between $1 \frac{1}{4}$ gr. $(75 \mathrm{mg}$.) and $13 \mathrm{gr}$. (780 mg.), averaging over $5 \mathrm{gr}$. (300 mg.). Out of 23 patients whose records are complete 21 took cocaine as well as heroin, usually in equal quantities. 